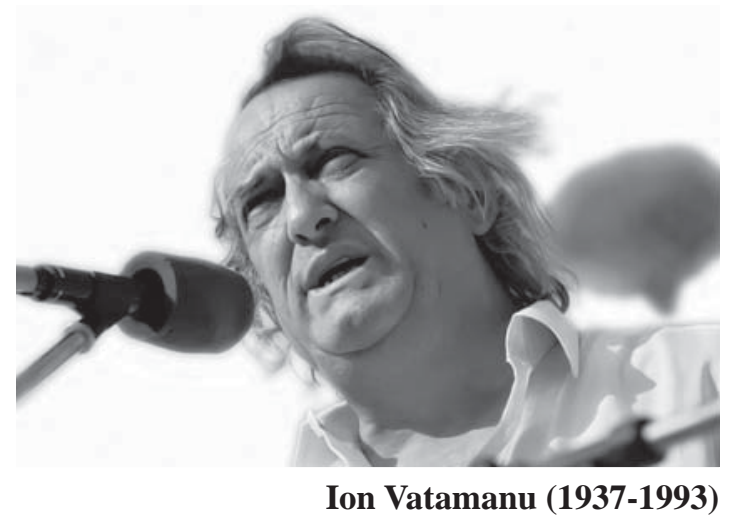

\title{
In memoriam Ion Vatamanu
}

(Commemorating the $75^{\text {th }}$ birth anniversary)

"I have studied the valences of the world: the bound and the unbound,/ The limiting and the endless/ Captured in the circular bond of thought" [1] - these verses represent a confluence of Ars Poetica and the scientific method, a relentless and impassioned quest for knowledge through the exploration of metaphor. To the uninitiated, scientific research may be synonymous with painstaking drudgery in the confines of the laboratory, somewhat detrimenting creativity and intellectual fulfillment. Albert Einstein once said: "Imagination is more important than knowledge. For knowledge is limited to all we now know and understand, while imagination embraces the entire world, and all there ever will be to know and understand". Ion Vatamanu's afore quoted poem similarly invokes the universal valences of creativity. It also reveals the quintessence of his own personality: a true thinker and Renaissance man.

Ion Vatamanu's destiny would be marked by an indissoluble bond to the history of his motherland. He was born on May 1, 1937 in the village of Costiceni, Hotin County, in the Kingdom of Romania. The heavy reality of traumatically established post-World War II borders would be etched deeply in Ion Vatamanu's childhood. The beautiful and breathtaking landscapes of Bucovina and the nurturing love of his family - Ioan and Maria Vatamanu - molded the personality of the future scientist and poet. Following high school and a brief teaching job, the young Vatamanu enrolled at Moldova State University in Chişinău where he received his bachelor's degree in Chemistry in 1960. In the same year, Ion married Elena Curicheru, whose friendship and love would be a haven and muse for his creativity throughout his life. The journey from Bucovina to Moldova, from homeland to homeland, produced the literary first snow ("Primii Fulgi”, debut volume, 1962).

Fresh out of college, Ion Vatamanu dedicated himself to scientific research. In 1971 he successfully defended his doctoral thesis "Oscillopolarografic investigation of bismuth, zinc, and antimony complexes and their applications in analytical chemistry" at Lviv University, Ukraine. In 1973 he was appointed principal investigator and laboratory head at the Institute of Chemistry of the Academy of Sciences of the Republic of Moldova. As a chemist, Ion Vatamanu authored and co-authored over 150 scientific publications in analytical chemistry. His research yielded observations of practical value and earned him five patents on oscillopolarographic applications (1980-1989), whose underlying methodologies were thereafter implemented at industrial scale. In collaboration with his colleagues, Ion Vatamanu published several analytical chemistry books (for a summary, see [2]). In 1988 he co-authored (with Dr. Ilie Fiştic) the monograph "The thermodynamics of metal ion hydrolysis".

In scientific circles, Ion Vatamanu was thus known for his accomplishments in analytical chemistry, yet he also emerged as a distinct literary voice. Chemistry and poetry intertwine in an inseparable duality in Ion Vatamanu's life, not unlike the wave-particle nature of light. From inception, Vatamanu's poetry would irreversibly change Chişinău's literary landscape, inducing a paradigm shift. His poems transpose the reader to a universe of multifaceted emotion, with titles crafted in inspiration that encourage lyrical and philosophical reflection. In an eloquent literary analysis, the academician Mihai Cimpoi praised the genuinely innovative spirit of Ion Vatamanu's poetry (Foreword to "Altă iubire nu este", Biodova, 2001). The numerous poetry books and literary essays that Ion Vatamanu authored over the years have become an integral part of the national cultural patrimony. The esthetics of his works continues to provide literary critics and theorists with venues for exploration.

This portrait into Ion Vatamanu's life would prove incomplete with no mention of his journalistic work - during 1989-1991 he led, along with writer Leonida Lari, the newspaper "Glasul”, the first post-World War II publication in the Republic of Moldova to use the Latin alphabet, and in 1991-1993 he was the director of the journal "Columna". Additionally, he translated poems by American, Greek, Latvian, Lithuanian, Russian, and Ukrainian authors. As a member of the first Parliament of the Republic of Moldova (1990-1993), within which he also acted as head of the 
Parliamentary Commission for Culture and Religion, he participated in numerous events of historical note, including the signing of the Declaration of Independence of the Republic of Moldova. His talent as an orator was on full display during the Great National Assembly in Chişinău, wherein he delivered vibrant patriotic speeches. Ion Vatamanu's unexpected death on August 9, 1993 would be an early end for his creative endeavors. Reaching into my own memories, I try to recall how I got to know Ion Vatamanu. My parents' passion for literature introduced me to his poems at a young age, and I enjoyed revisiting his unmistakable metaphors in my classes as well. I remember, as an undergraduate at Moldova State University, a particularly inspiring talk-show conversation between Ion Vatamanu and the chemistry and philology students making up the invitees, covering topics ranging from chemistry to poetry and philosophy. Later on, as I started my research career as a chemist, I had the pleasure of knowing Ion Vatamanu during his tenure at the Institute of Chemistry of the Academy of Sciences of the Republic of Moldova. I have always admired his imagination, eloquence, honesty, and passion for knowledge, while our shared intellectual interests gave rise to a great lifelong friendship.

A dreamer in his creative solitude, an objective and lucid analyst of history and contemporaneity, an energetic and decisive leader with an uncanny ability for crisis management - all these describe Ion Vatamanu. His wife Elena and daughters Mihaela, Mariana, Leontina treasure a personal universe in which the magical spark of Ion Vatamanu's love and joy of life meld the everyday in and out of poetry. Ion Vatamanu's instantaneous connection to the audiences and deeply felt words still touch the hearts of his many colleagues and friends. But perhaps the most vivid and overwhelming memory is captured in the title of the documentary produced by his daughter Leontina, “Dor de Ion Vatamanu” [3]. This succinct metaphor encompasses all the love and gratitude with which Ion Vatamanu will forever be remembered by all those who had the privilege to have known him.

\author{
Dr. Sergiu Petru Palii \\ University of Florida, USA \\ May 1, 2012
}

\title{
References
}

[1]. Original Romanian text: "Am studiat valențele lumii: ceea ce se leagă/ şi ceea ce nu se leagă,/ Mărginirea şi nemărginirea/ Intr-o legătură rotundă a gândirii" (Ion Vatamanu, "Cuvinte de cretă ”).

[2]. Tudor Lupascu, Pavel F. Vlad, Aculina Aricu, Maria Cocu. Achievements of the Institute of Chemistry of the Academy of Sciences of Moldova at 50 years anniversary, Chemistry Journal of Moldova, 2009, 4 (1), 8-16.

[3]. Documentary "Dor de Ion Vatamanu” directed by Leontina Vatamanu. OWH TV Studio, Moldova, 2007. The Romanian word "dor" evokes a combination of longing, love, and sadness. It is both a concept and a metaphor and thus eludes adequate translation. 